\title{
tri-n-Butyltin Hydride-Mediated Radical Reaction of a 2-Iodobenzamide: Formation of an Unexpected Carbon-Tin Bond
}

\author{
Marcelo T. Oliveira, ${ }^{a}$ Maria Auxiliadôra F. Prado, ${ }^{* b}$ Rosemeire B. Alves, ${ }^{a}$ Amary Cesar, ${ }^{a}$ \\ Ricardo J. Alves, ${ }^{b}$ Carla G. Queiroga, ${ }^{b}$ Leonardo S. Santos ${ }^{c}$ and Marcos N. Eberlin ${ }^{d}$ \\ ${ }^{a}$ Departamento de Química, Instituto de Ciências Exatas and ${ }^{b}$ Departamento de Produtos Farmacêuticos, \\ Faculdade de Farmácia,Universidade Federal de Minas Gerais, Avenida Antônio Carlos 6627, \\ 31270-901 Belo Horizonte-MG, Brazil \\ ${ }^{c}$ Instituto de Química de Recursos Naturales, Universidad de Talca, P.O. Box 747, Talca - Chile \\ ${ }^{d}$ Instituto de Química, Universidade Estadual de Campinas, 13083-970, Campinas- SP, Brazil
}

\begin{abstract}
A reação radicalar mediada por hidreto de tri- $n$-butilestanho de 2,3-di-O-benzil-4- $O$-transcinamil-6-desoxi-6-(2-iodobenzoilamino)- $\alpha$-D-galactopyranosídeo de metila levou à formação de um produto inesperado, o 2,3-di-O-benzil-4- $O$-trans-cinamil-6-desoxi-6-(2-tri- $n$ butilestanhobenzoilamino)- $\alpha$-D-galactopyranosídeo de metila. A estrutura do produto foi elucidada por meio das espectrometrias de RMN unidimensionais $\left({ }^{1} \mathrm{H},{ }^{13} \mathrm{C}\right.$ e DEPT) e bidimensionais (COSY e HMQC) e confirmada por espectrometria de massas. Foram apresentadas propostas de mecanismos para explicar a formação do derivado organoestanho.

The tri- $n$-butyltin hydride-mediated reaction of methyl 2,3-di- $O$-benzyl-4-O-trans-cinnamyl6-deoxy-6-(2-iodobenzoylamino)- $\alpha$-D-galactopyranoside afforded an unexpected aryltributyltin compound. The structure of this new tetraorganotin(IV) product has been elucidated by ${ }^{1} \mathrm{H},{ }^{13} \mathrm{C}$ NMR spectroscopy, COSY and HMQC experiments and electrospray ionization mass spectrometry (ESI-MS). The formation of this new compound via a radical coupling reaction and a radical addition-elimination process is discussed.
\end{abstract}

Keywords: tetraorganotin, arylstannane, aryl radical cyclization, 2-iodobenzamide

\section{Introduction}

In our studies of $\mathrm{Bu}_{3} \mathrm{SnH}$-mediated radical cyclizations, we have applied unsaturated organohalides to synthesize large- and medium-size heterocycles..$^{1-8}$ Most particularly, ortho-iodobenzamides bearing a side allyloxy group have been used to form benzomacrolactams with 11-, 12- and 20membered ring via regioselective endo aryl radical cyclization..$^{1-5}$ In this context, the benzamide methyl 4-Oallyl-2,3-di- $O$-benzyl-6-deoxy-6-(2-iodobenzoylamino)- $\alpha$ D-galactopyranoside (1) was found to give the benzomacrolactam 2 owing to 11-endo cyclization in $32 \%$ yield. ${ }^{2}$

To continue these studies, we applied the $\mathrm{Bu}_{3} \mathrm{SnH}-$ mediated radical reaction in an attempt to form the benzomacrolactams 3 and/or $\mathbf{4}$ from methyl 2,3-di-O-benzyl4-O-trans-cinnamyl-6-deoxy-6-(2-iodobenzoylamino)- $\alpha$-Dgalactopyranoside (5), a cinnamylated analogue of $\mathbf{1}$. Despite our knowledge of preferential endo cyclization mode over

*e-mail: pradora@farmacia.ufmg.br the exo-mode in macrocyclization reactions,,$^{1-5,9-16}$ we expected that 10-exo cyclization could also occur due to the higher stability of the benzyl radical. This hypothesis was supported by the observation that precursors with cinnamyl group provided macrocycle intermediates resulting from 10exo carbocyclization. ${ }^{6}$ Moreover, the cinnamyl moiety of 5 would generate a new stereogenic center upon 10-exo or 11-endo cyclization, hence the stereoselectivity of the reaction could be evaluated. In fact, the tri- $n$-butyltin hydridemediated reaction of $\mathbf{5}$ afforded an unexpected aryltributyltin compound.

\section{Results and Discussion}

To prepare the iodobenzamide 5, the C-4 and C-6 hydroxyl groups of methyl $\alpha$-D-galactopyranoside were protected as benzylidene acetal ${ }^{17}$ and the $\mathrm{C}-2$ and C-3 hydroxyl groups were $O$-benzylated. ${ }^{18}$ Removal of the benzylidene group ${ }^{19}$ following by regioselective replacement of the hydroxyl group at C-6 by iodine atom, ${ }^{2,20}$ substitution 

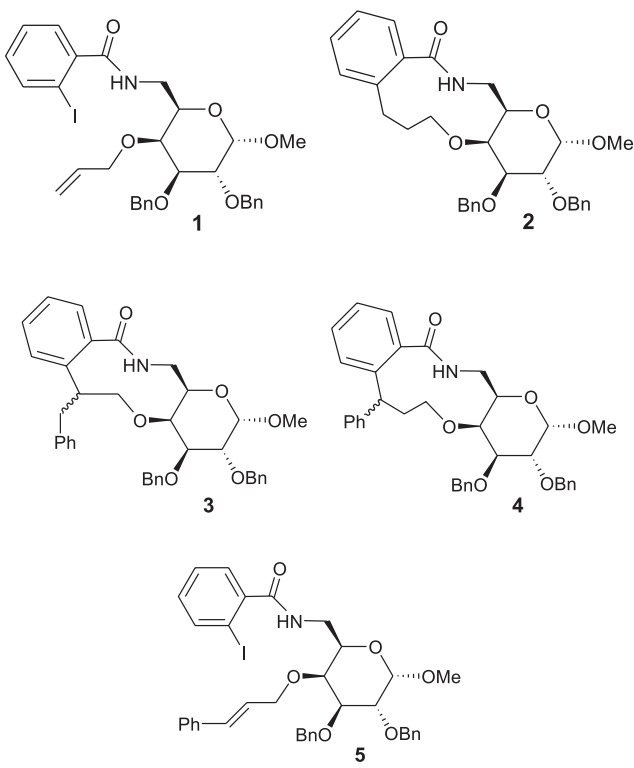

of iodine atom by azido group ${ }^{2,21}$ and $O$-cinnamylation of $\mathrm{C}$ 4 hydroxyl group ${ }^{22}$ gave the methyl 6-azido-2,3-di- $O$-benzyl4-O-trans-cinnamyl-6-deoxy- $\alpha$-D-galactopyranoside (6). Selective reduction of the azido group ${ }^{23}$ gave the expected amine 7, which upon treatment with 2-iodobenzoyl chloride ${ }^{24}$ furnished the desired iodobenzamide 5 (Scheme 1).

The radical reaction was carried out with slow addition of $\mathrm{Bu}_{3} \mathrm{SnH} / \mathrm{AIBN}$ to a benzene solution of $\mathbf{5}$ and very low concentrations of both $\mathbf{5}$ and $\mathrm{Bu}_{3} \mathrm{SnH}(0.013$ mol $\mathrm{L}^{-1}$ ). These reaction conditions are recommended to improve the formation of cyclized products and to decrease the intermolecular reactions and the rate of hydrogen atom transfer to uncyclized radicals. ${ }^{25-28}$ Two main products were formed in the radical reaction: the unexpected tetraorganotin(IV) compound $\mathbf{8}$ in $29 \%$ yield and the uncyclized reduced product 9 in $27 \%$ yield (Scheme 1).
The hydrogenolysis product 9 was readily identified from its ${ }^{1} \mathrm{H}$ and ${ }^{13} \mathrm{C}$ NMR data. The structure of 8 required a detailed analysis of the NMR spectra $\left({ }^{1} \mathrm{H},{ }^{13} \mathrm{C}\right.$ and DEPT) and connectivity studies by COSY and HMQC experiments. The NMR spectra indicated the presence of a single aromatic hydrogen $(\delta 7.63)$ more deshielded than the others eighteen aromatic hydrogens and five ipso carbons. Two of these ipso carbon atoms show chemical shifts compatibles with aryl carbons bound to tin and ortho to $\operatorname{tin}^{29,30}(\delta 139.8$ and 145.7). Signals of $3 n$-butyl moieties bound to $\mathrm{Sn},{ }^{29-31}$ cinnamyloxy group, methyl galactopyranoside moiety and benzamide were also observed. Table 1 lists selected data of ${ }^{1} \mathrm{H}$ and ${ }^{13} \mathrm{C}$ spectra for iodobenzamide $\mathbf{5}$, tetraorganotin compound $\mathbf{8}$ and hydrogenolysis product $\mathbf{9}$.

The ESI(+)-MS spectrum was also found to be fully compatible with the structure of the organotin product 8. It shows major ions due to cationized forms of $\mathbf{8}$, that is, of $\mathrm{m} / \mathrm{z} 906.3898(\mathrm{~m} / \mathrm{z} 906.3743$ calculated for $\left.\left[\mathrm{C}_{49} \mathrm{H}_{65} \mathrm{NO}_{6} \mathrm{Sn}+\mathrm{Na}\right]^{+}\right)$and $\mathrm{m} / z 922.3260(\mathrm{~m} / z .922 .3481$ calculated for $\left[\mathrm{C}_{49} \mathrm{H}_{65} \mathrm{NO}_{6} \mathrm{Sn}+\mathrm{K}\right]^{+}$) with a cluster of isotopologue ions characteristic for the presence of $\mathrm{Sn}$ multi-isotope element.

Only two articles that describe the isolation of aryltri$n$-butyltin compounds, as by-products, from $\mathrm{Bu}_{3} \mathrm{SnH}$ mediated aryl radical cyclization were found in the literature. ${ }^{32,33}$ Moreover, the formation of this kind of stannylated compound was not observed in our previous studies. ${ }^{1-5}$ The formation of aryltributyltin compounds is described using other methods. ${ }^{34,35}$

One possible rationalization for the formation of the tri- $n$-butylaryltin compound $\mathbf{8}$ is via the coupling of the aryl and tri- $n$-butyltin radicals, since chain termination steps can occur in radical reactions. ${ }^{27,36}$ Other plausible proposals can not be ruled out. For instance, the formation

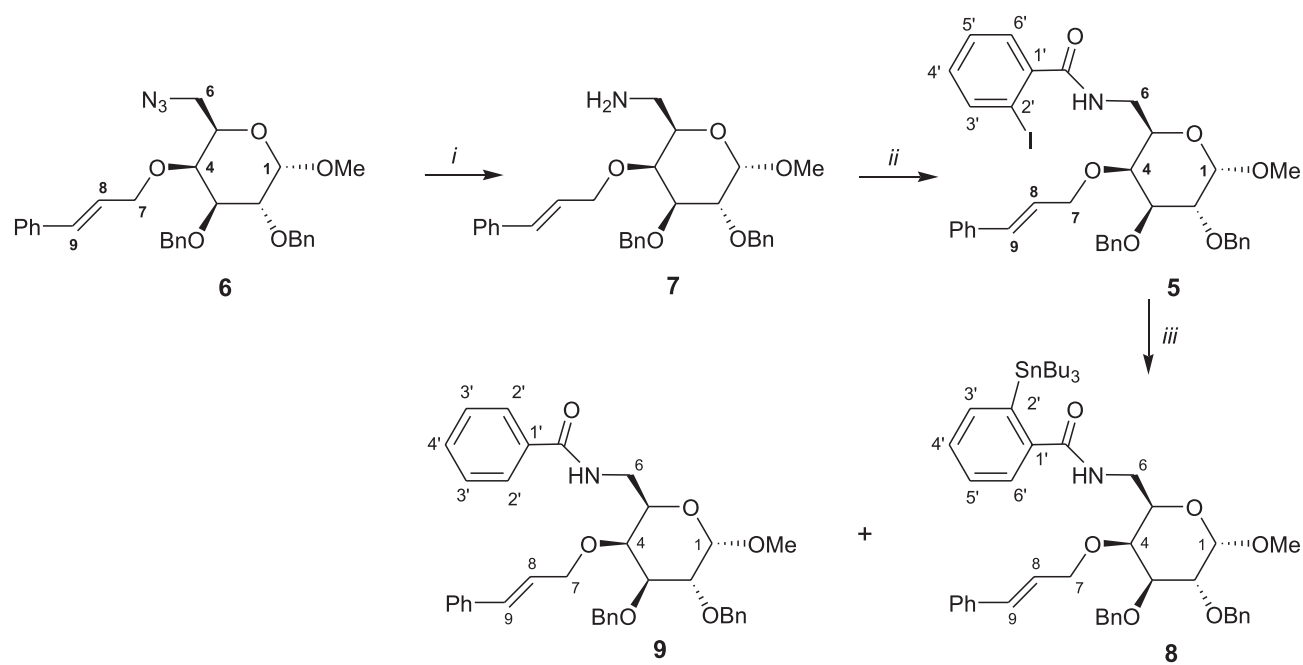

Scheme 1. Reagents, conditions and yields. $i$ : $\mathrm{LiAlH}_{4}$, THF, rt; ii: 2-iodobenzoyl chloride, $10 \% \mathrm{NaOH}_{\text {(aq.) }} \mathrm{CH}_{2} \mathrm{Cl}_{2}$, rt, $44 \%$ (over the steps $i$ and ii); iii: $\mathrm{Bu}_{3} \mathrm{SnH}, \mathrm{AIBN}$, benzene, reflux, $829 \%, 927 \%$. 
Table 1. Selected ${ }^{1} \mathrm{H}$ and ${ }^{13} \mathrm{C}$ NMR data for compounds 5, 8 and 9

\begin{tabular}{|c|c|c|c|c|c|}
\hline \multirow[t]{2}{*}{ Compound } & \multicolumn{2}{|c|}{$\begin{array}{c}{ }^{1} \mathrm{H} \text { NMR } \\
\delta\end{array}$} & \multicolumn{3}{|c|}{$\begin{array}{c}{ }^{13} \mathrm{C} \text { NMR } \\
\delta\end{array}$} \\
\hline & aromatic $\mathrm{H}$ & $n$-butyl $\mathrm{H}^{a}$ & $\mathrm{C}=\mathrm{O}$ & ipso $\mathrm{C}$ & $n$-butyl $\mathrm{C}^{a}$ \\
\hline 5 & $\begin{array}{l}7.80,1 \mathrm{H}, \mathrm{d}, \\
7.9 \mathrm{~Hz}\left(3^{\prime}\right)\end{array}$ & - & 169.5 & $\begin{array}{c}142.0\left(1^{\prime}\right) \\
138.6,138.5(\text { benzyl }) \\
136.4(\text { cinnamyl }) \\
92.4\left(2^{\prime}\right)\end{array}$ & - \\
\hline 9 & $\begin{array}{l}\text { 7.68, } 2 \mathrm{H}, \mathrm{d}, \\
7.4 \mathrm{~Hz}\left(2^{\prime}\right)\end{array}$ & - & 167.7 & $\begin{array}{c}138.8,138.6 \text { (benzyl) } 136.6 \\
\text { (cinnamyl) } \\
134.4\left(1^{\prime}\right)\end{array}$ & - \\
\hline 8 & $\begin{array}{c}\text { 7.63, } 1 \mathrm{H}, \mathrm{d}, \\
6.5 \mathrm{~Hz}\left(3^{\prime} \text { or 6') }\right.\end{array}$ & $\begin{array}{l}1.62-1.40,6 \mathrm{H}, \mathrm{m}(\beta) \\
1.34-1.19,12 \mathrm{H}(\alpha, \gamma) \\
0.84,9 \mathrm{H}, 7.1 \mathrm{~Hz}(\delta)\end{array}$ & 169.7 & $\begin{array}{l}145.7,139.8\left(1^{\prime}, 2^{\prime}\right)^{*} \\
138.8,138.7 \text { (benzyl) } \\
136.6(\text { cinnamyl })\end{array}$ & $\begin{array}{l}29.5(\beta) \\
27.7(\gamma) \\
13.9(\delta) \\
11.6(\alpha)\end{array}$ \\
\hline
\end{tabular}

* Respectively or not. ${ }^{a} \stackrel{\delta}{\mathrm{C}} \mathrm{H}_{3} \stackrel{\gamma}{\mathrm{C}} \mathrm{H}_{2} \stackrel{\beta}{\mathrm{C}} \mathrm{H}_{2} \stackrel{\alpha}{\mathrm{C}} \mathrm{H}_{2}-\mathrm{Sn}$

of $\mathbf{8}$ could be also attributed to the aromatic substitution by reaction of the reduced product 9 and the tri- $n$-butyltin radical in an addition-elimination process. ${ }^{37}$

The formation of $\mathbf{8}$, as the main product, by intermolecular reaction(s) was unexpected for us, since the reaction was carried out at low concentration of radicals, either by working at high dilution and by slow addition of $\mathrm{Bu}_{3} \mathrm{SnH}$. Additionally, the benzamide $\mathbf{1}$, which differs from $\mathbf{5}$ by the lack of the phenyl group, at the same reaction conditions gave the benzomacrolactam $2 .{ }^{2}$

To favour the desired cyclization reaction at the expense of reduction at the aryl radical to give $\mathbf{9}$ and formation of organotin compound $\mathbf{8}$, the reaction of $\mathbf{5}$ and $\mathrm{Bu}_{3} \mathrm{SnH}$ was carried out under two different conditions that were expected to disfavour intermolecular and reduction reactions..$^{25-28}$ When the addition of $\mathrm{Bu}_{3} \mathrm{SnH} / \mathrm{AIBN}$ solution was made over a longer period ( 2.5 hours instead of $1 \mathrm{~h}$ ) the yields of $\mathbf{8}$ and $\mathbf{9}$ reduced to $20 \%$ and $21 \%$, respectively. When the concentration of $\mathrm{Bu}_{3} \mathrm{SnH}$ was reduced to $0.0065 \mathrm{~mol} \mathrm{~L}^{-1}$ and the addition of the reagents was maintained to 2.5 hours none of $\mathbf{8}$ was formed and the hydrogenolysis product $\mathbf{9}$ was obtained in $25 \%$ yield. In both experiments none of the cyclized product was isolated.

The absence of cyclization product from $\mathbf{5}$, in contrast with the radical reaction of $\mathbf{1}$, can be attributed to the steric hindrance between the phenyl ring of the cinnamyl group and the attacking aryl radical in the preferential endo-mode. Other possible explanation for this would be the generation of aryl radical followed by intramolecular hydrogen-atom transfer from the allyl group to the aryl group with the formation of a stable cinnamyl radical, which undergoes reduction to give $\mathbf{9}$.
In conclusion, $\mathrm{Bu}_{3} \mathrm{SnH}$-induced aryl radical cyclization of methyl 2,3-di-O-benzyl-4-O-trans-cinnamyl-6-deoxy6-(2-iodobenzoylamino)- $\alpha$-D-galactopyranoside (5) fails to proceed through the expected 10-exo and 11-endo modes that would afford the 10- and 11-membered lactams $\mathbf{3}$ and $\mathbf{4}$, respectively. Instead, $\mathbf{5}$ gives the hydrogenolysis product $\mathbf{9}$ and the aryltributyltin compound $\mathbf{8}$, as indicated by MS and NMR data.

\section{Experimental}

\section{General procedures}

All melting points were determined on a Microquimica MQAPF-301 apparatus and are uncorrected. Optical rotations were determined at $25{ }^{\circ} \mathrm{C}$ with a Perkin Elmer 341 Polarimeter. The IR spectra were recorded on a Mattson Instruments Galaxy 3000 spectrometer. The NMR spectra were measured in deuteriochloroform with TMS as the internal standard with a Bruker Avance DRX-400 or a Bruker Avance200 instruments. Chemical shifts are given in $\delta$ scale and $J$ values are given in Hz. ESI(+)-MS spectra were obtained using a Micromass QTof hybrid quadrupole time-of-flight mass spectrometer operating at 7.000 mass resolution and $5 \mathrm{ppm}$ mass accuracy using typical analytical conditions as described elsewhere. ${ }^{38}$ ESI-MS spectra for mass measurements were taken using both positive- and negative-ion mode from 1:1 $\mathrm{H}_{2} \mathrm{O}-\mathrm{MeOH}$ solutions with addition of either a few microlitres of formic acid or ammonium hydroxide. Column chromatography was performed with silica gel 60, 70230 mesh (Merck). The term "standard work-up" means 
that the organic layer was washed with water, dried over anhydrous sodium sulfate, filtered and the solvent was removed under reduced pressure. The new carbohydrate derivatives 5, 6 and 7 were prepared according to published procedures. ${ }^{22-24}$ The radical reaction was carried out using standard procedure. ${ }^{1,2,25,26}$

Methyl 6-azido-2,3-di-O-benzyl-4-O-trans-cinnamyl-6deoxy- $\alpha$-D-galactopyranoside (6)

To a solution of methyl 6-azido-2,3-di- $O$-benzyl-6deoxy- $\alpha$-D-galactopyranoside $(0.40 \mathrm{~g}, 1.0 \mathrm{mmol})$ in $\mathrm{CH}_{2} \mathrm{Cl}_{2}(8 \mathrm{~mL})$ were added, under magnetic stirring, $50 \%$ $(\mathrm{m} / \mathrm{v})$ aqueous $\mathrm{NaOH}(3 \mathrm{~mL})$ and $\mathrm{Bu}_{4} \mathrm{NBr}(0.48 \mathrm{~g}, 1.5$ $\mathrm{mmol})$, as phase transfer catalyst. The mixture was stirred for 15 minutes. Cinnamyl bromide $(0.51 \mathrm{~g}, 2.6 \mathrm{mmol})$ was added and the mixture was stirred for $18 \mathrm{~h}$ at room temperature. The organic layer was separated and the aqueous layer was extracted with $\mathrm{CH}_{2} \mathrm{Cl}_{2}$. Standard workup gave a residue, which was submitted to column chromatography. The compound $6(0.45 \mathrm{~g}, 0.87 \mathrm{mmol}$, $87 \%$ ), eluted with hexane-ethyl acetate 8:2 (v/v), was obtained as a syrup; $[\alpha]_{\mathrm{D}}+22.5\left(c 2.00, \mathrm{CHCl}_{3}\right)$; IR $\mathrm{v}_{\max }$ ' $\mathrm{cm}^{-1}: 2100\left(\mathrm{~N}_{3}\right) ;{ }^{1} \mathrm{H}$ NMR $\left(200 \mathrm{MHz}, \mathrm{CDCl}_{3}, \delta, J \mathrm{~Hz}\right)$ 7.73-7.24 (15 H, m, Ar); $6.52\left(1 \mathrm{H}, \mathrm{d}, J_{9,8} 15.9,9-\mathrm{H}\right)$; 6.32-6.18 (1 H, m, 8-H); 4.87 (1 H, d, $J_{\text {gem }} 11.8$, one of $\left.\mathrm{PhCH}_{2}\right) ; 4.85$ ( $1 \mathrm{H}, \mathrm{d}, \mathrm{J}_{\text {gem }} 11.8$, one of $\left.\mathrm{PhCH}_{2}\right)$; 4.54$4.75\left(4 \mathrm{H}, \mathrm{m}\right.$, two of $\mathrm{PhCH}_{2}, 1-\mathrm{H}$, one of $\left.7-\mathrm{H}\right) ; 4.26(1 \mathrm{H}$, dd, $J_{\text {gem }} 12.4 J_{7,8} 6.9$, one of 7-H); $4.00\left(1 \mathrm{H}, \mathrm{dd}, J_{2,3} 9.9\right.$ $\left.J_{2,1} 3.4,2-\mathrm{H}\right) ; 3.92-3.91$ (1 H, m, sugar $\left.\mathrm{H}\right), 3.87-3.77$ (2 $\mathrm{H}$, sugar $\mathrm{H}) ; 3.60\left(1 \mathrm{H}\right.$, dd, $J_{\text {gem }} 12.4, J_{6,5} 7.9$, one of $6-$ $\mathrm{H}) ; 3.40$ (3 H, s, MeO); 3.19 (1 H, dd, $J_{6.5} 4.8$, one of 6$\mathrm{H}) ;{ }^{13} \mathrm{C} \mathrm{NMR}\left(50 \mathrm{MHz}, \mathrm{CDCl}_{3}, \delta\right.$ ) 138.8, 138.6 (2 ipso $\mathrm{C}$ of benzyl groups); 136.7 (ipso $\mathrm{C}$ of cinnamyl group); 128.8, 128.6, 128.2, 128.0, 127.8, 127.7 (Ar); 126.2 (8C); 99.0 (1-C); 78.8, 76.6, 75.5 (sugar C); 73.8, 73.7, $73.3\left(2 \times \mathrm{PhCH}_{2}\right.$ and 7-C); 79.9 (sugar C); $55.4(\mathrm{MeO})$; $51.5(6-\mathrm{C})$.

Methyl 6-amino-2,3-di-O-benzyl-4-O-trans-cinnamyl-6deoxy- $\alpha$-D-galactopyranoside (7)

To a suspension of lithium aluminum hydride $(48 \mathrm{mg}$, $1.3 \mathrm{mmol})$ in THF $(5 \mathrm{~mL})$ was added a solution of methyl 6-azido-2,3-di-O-benzyl-4-O-trans-cinnamyl-6-deoxy- $\alpha$ D-galactopyranoside $6(0.30 \mathrm{~g}, 0.58 \mathrm{mmol})$ in THF $(4 \mathrm{~mL})$. The solution was stirred for $24 \mathrm{~h}$ at room temperature. Water $(2 \mathrm{~mL}), 5 \%(\mathrm{~m} / \mathrm{v})$ aqueous $\mathrm{NaOH}(1 \mathrm{~mL})$ and $\mathrm{CH}_{2} \mathrm{Cl}_{2}(10$ $\mathrm{mL}$ ) were added. The organic layer was separated and the aqueous layer was extracted with $\mathrm{CH}_{2} \mathrm{Cl}_{2}$. Standard workup gave a residue which was not purified.
Methyl 2,3-di-O-benzyl-4-O-trans-cinnamyl-6-deoxy-6-(2iodobenzoylamino)- $\alpha$-D-galactopyranoside (5)

To a solution of 2-iodobenzoyl chloride $(0.40 \mathrm{~g}, 1.5$ $\mathrm{mmol})$ in $\mathrm{CH}_{2} \mathrm{Cl}_{2}(5 \mathrm{~mL})$ were added $10 \%(\mathrm{~m} / \mathrm{v})$ aqueous $\mathrm{NaOH}(2 \mathrm{~mL})$ and a solution of methyl 6-amino-2,3-di$O$-benzyl-4- $O$-trans-cinnamyl-6-deoxy- $\alpha$-D-galactopyranoside 7 , obtained as described above, in $\mathrm{CH}_{2} \mathrm{Cl}_{2}$ (5 $\mathrm{mL})$. The mixture was stirred for $16 \mathrm{~h}$ at room temperature. The organic layer was separated and the aqueous phase was extracted with $\mathrm{CH}_{2} \mathrm{Cl}_{2}$. Standard work-up gave a residue, which was submitted to column chromatography. The iodobenzamide 5 (0.18 g, $0.26 \mathrm{mmol}, 44 \%$ from 6$)$, eluted with hexane-ethyl acetate $6: 4(\mathrm{v} / \mathrm{v})$, was obtained as a white solid; mp 144.8-150.2 ${ }^{\circ} \mathrm{C}$; $[\alpha]_{\mathrm{D}}+20.4(c$ 2.70, $\left.\mathrm{CHCl}_{3}\right)$; IR $v_{\max } / \mathrm{cm}^{-1}: 3250(\mathrm{NH}), 1650(\mathrm{C}=\mathrm{O}) ;{ }^{1} \mathrm{H}$ NMR (400 MHz, $\left.\mathrm{CDCl}_{3}, \delta, J \mathrm{~Hz}\right) 7.80$ (1 H, d, J ${\text { 3, } 4^{\prime}}^{\prime} 7.9,3^{\prime}-\mathrm{H})$; 7.40-7.22 (17 H, m, Ar); 7.02-7.08 (1 H, m, Ar); 6.52 (1 $\left.\mathrm{H}, \mathrm{d}, J_{9,8} 15.9,9-\mathrm{H}\right) ; 6.27\left(1 \mathrm{H}, \mathrm{dt}, J_{8,7}=J_{8,7}, 6.9,8-\mathrm{H}\right)$; $6.18\left(1 \mathrm{H}, \mathrm{dd}, J_{\mathrm{NH}, 6} 5.2, J_{\mathrm{NH}, 6}, 3.6, \mathrm{~N}-H\right) ; 4.86\left(1 \mathrm{H}, \mathrm{d}, J_{\text {gem }}\right.$ 11.8, one of $\left.\mathrm{PhCH}_{2}\right) ; 4.85\left(1 \mathrm{H}, \mathrm{d}, \mathrm{J}_{\text {gem }} 11.9\right.$, one of $\left.\mathrm{PhCH}_{2}\right)$; $4.73\left(1 \mathrm{H}, \mathrm{d}, J_{\text {gem }} 11.9\right.$, one of $\left.\mathrm{PhCH}_{2}\right) ; 4.68\left(1 \mathrm{H}, \mathrm{d}, J_{\text {gem }}\right.$ 11.8, one of $\left.\mathrm{PhCH}_{2}\right) ; 4.67\left(1 \mathrm{H}, \mathrm{d}, J_{1,2} 3.5,1-\mathrm{H}\right) ; 4.31$ (1 $\mathrm{H}$, dd, $J_{\text {gem }} 12.4 J_{7,8} 7.0$, one of 7-H); $4.00\left(1 \mathrm{H}, \mathrm{dd}, J_{2,3}\right.$ 9.7, $J_{2,1}$ or $J_{3,4} 3.5,2-\mathrm{H}$ or $\left.3-\mathrm{H}\right) ; 3.97-3.91$ (4 H, m, sugar $\mathrm{H}$, one of 7-H); 3.46-3.39 (2 H, m, sugar H); 3.37 (3 H, s, $\mathrm{MeO}) ;{ }^{13} \mathrm{C} \mathrm{NMR}\left(100 \mathrm{MHz}, \mathrm{CDCl}_{3}, \delta\right) 169.5(\mathrm{C}=\mathrm{O}) ; 142.0$ (1'-C); 140.0 (3'-C); 138.6, 138.5 (2 ipso C of benzyl groups); 136.4 (ipso $\mathrm{C}$ of cinnamyl group); 133.5 (9-C); 131.1, 128.6, 128.5, 128.4, 128.3, 128.1, 128.0, 127.8, 127.9, 127.7, 127.6 (Ar); 126.6 (8-C); 99.0 (1-C); 92.4 (2'-C); 78.6, 76.4, 76.3 (sugar C); 73.7, 73.6, 73.5 (2× $\mathrm{PhCH}_{2}$ and 7-C); 68.7 (sugar C); 55.8 (MeO); 40.9 (6-C); ESI(+)-MS $\mathrm{m} / \mathrm{z}$ found: $720.1552, \mathrm{~m} / \mathrm{z}$ calculated for $\left[\mathrm{C}_{37} \mathrm{H}_{38} \mathrm{INO}_{6}+\mathrm{H}\right]^{+}:$720.1822; $\mathrm{m} / \mathrm{z}$ found: $742.1527, \mathrm{~m} / \mathrm{z}$ calculated for $\left[\mathrm{C}_{37} \mathrm{H}_{38} \mathrm{INO}_{6}+\mathrm{Na}\right]^{+}:$742.1642.

\section{Radical reaction of compound 5}

To a stirring and boiling solution of compound 5 (0.20 $\mathrm{g}, 0.28 \mathrm{mmol})$ in nitrogen-saturated benzene $(27 \mathrm{~mL})$ was added a solution of $\mathrm{Bu}_{3} \mathrm{SnH}(0.13 \mathrm{~mL}, 0.14 \mathrm{~g}, 0.49 \mathrm{mmol})$ and AIBN (18 mg) in nitrogen-saturated benzene $(10 \mathrm{~mL})$ via an addition funnel during $1 \mathrm{~h}$. The reaction mixture was heated under reflux and nitrogen atmosphere for a further $1 \mathrm{~h}$. Subsequent solvent removal and column chromatography gave, successively, the organotin compound 8 (72 mg, $0.082 \mathrm{mmol}, 29 \%$ ), eluted with hexane-ethyl acetate 8:2(v/v), and the hydrogenolysis product 9 (45 mg, $0.076 \mathrm{mmol}, 27 \%)$, eluted with hexaneethyl acetate $6: 4(\mathrm{v} / \mathrm{v})$. The organotin compound 8 was 
obtained as a white solid; mp 47.5-50.0 ${ }^{\circ} \mathrm{C} ;[\alpha]_{\mathrm{D}}+9.9(c$ 0.93, $\left.\mathrm{CHCl}_{3}\right) ; \mathrm{IR} v_{\max } / \mathrm{cm}^{-1}: 3350(\mathrm{NH}), 1610(\mathrm{C}=\mathrm{O}) ;{ }^{1} \mathrm{H}$ NMR $\left(200 \mathrm{MHz}, \mathrm{CDCl}_{3}, \delta, J \mathrm{~Hz}\right) 7.63\left(1 \mathrm{H}, \mathrm{d}, J_{\text {orto }} 6.5\right.$, 3'-H or 6'-H); 7.41-7.13 (18 H, m, Ar, N-H); 6.54 (1 H, d, $\left.J_{8,9} 16.2,9-\mathrm{H}\right) ; 6.36-6.31(1 \mathrm{H}, \mathrm{m}, 8-\mathrm{H}) ; 4.87\left(1 \mathrm{H}, \mathrm{d}, J_{\text {gem }}\right.$ 10.5, one of $\left.\mathrm{PhCH}_{2}\right) ; 4.76-4.56\left(4 \mathrm{H}, \mathrm{m}, 3\right.$ of $\mathrm{PhCH}_{2}$, one of 7-H); $4.70\left(1 \mathrm{H}, \mathrm{d}, J_{1,2} 3.6,1-\mathrm{H}\right) ; 4.29\left(1 \mathrm{H}, \mathrm{dd}, J_{\text {gem }}\right.$ $11.9, J_{7,8} 6.3$, one of $\left.7-\mathrm{H}\right) ; 4.02\left(1 \mathrm{H}, \mathrm{dd}, J_{2,3} 9.5,2-\mathrm{H}\right)$; 3.94-3.88 (4 H, m, 5-H, 4-H, 3-H, one of 6-H); 3.50-3.35 $(1 \mathrm{H}, \mathrm{m}$, one of $6-\mathrm{H}) ; 3.31(3 \mathrm{H}, \mathrm{s}, \mathrm{MeO}) ; 1.62-1.40$ (6 H, m, $\left.\mathrm{SnCH}_{2} \mathrm{CH}_{2} \mathrm{CH}_{2} \mathrm{CH}_{3}\right) ; 1.34-1.19(12 \mathrm{H}, \mathrm{m}$, $\left.\mathrm{SnCH}_{2} \mathrm{CH}_{2} \mathrm{CH}_{2} \mathrm{CH}_{3}\right) ; 0,84$ (9 H, t, $J$ 7.1, $\mathrm{CH}_{3}$ of $n$-butyl group); ${ }^{13} \mathrm{C} \mathrm{NMR}\left(50 \mathrm{MHz}, \mathrm{CDCl}_{3}, \delta\right) 169.7(\mathrm{C}=\mathrm{O}) ; 145.7$, 139.8 (1'-C, 2'-C); 138.8, 138.7 (2 ipso $\mathrm{C}$ of benzyl groups); 137.7 (3'-C); 136.6 (ipso $\mathrm{C}$ of cinnamyl group); 133.4 (9-C); 130.5, 128.8, 128.7, 128.6, 128.1, 128.0, 127.9, 127.8, 126.8, $126.2(\mathrm{Ar}) ; 125.2(8-\mathrm{C}) ; 99.1$ (1-C); 79.0, 76.7, 76.6 (2-C, 3-C, 4-C); 73.9, $73.7\left(2 \times \mathrm{PhCH}_{2}\right.$, 7-C); 68.8 (5-C); $55.6(\mathrm{MeO}) ; 41.2$ (6-C); 29.5 $\left(\mathrm{SnCH}_{2} \mathrm{CH}_{2} \mathrm{CH}_{2} \mathrm{CH}_{3}\right), 27.7\left(\mathrm{SnCH}_{2} \mathrm{CH}_{2} \mathrm{CH}_{2} \mathrm{CH}_{3}\right) ; 13.9$ $\left(\mathrm{CH}_{3}\right.$ of $n$-butyl group); $11.6\left(\mathrm{SnCH}_{2} \mathrm{CH}_{2} \mathrm{CH}_{2} \mathrm{CH}_{3}\right)$; [ESI(+)-MS] $\mathrm{m} / \mathrm{z}$ found: $906.3898, \mathrm{~m} / \mathrm{z}$ calculated for $\left[\mathrm{C}_{49} \mathrm{H}_{65} \mathrm{NO}_{6} \mathrm{Sn}+\mathrm{Na}\right]^{+}:$906.3743; $\mathrm{m} / \mathrm{z}$ found: 922.3260 , $\mathrm{m} / \mathrm{z}$ calculated for $\left[\mathrm{C}_{49} \mathrm{H}_{65} \mathrm{NO}_{6} \mathrm{Sn}+\mathrm{K}\right]^{+}:$922.3481. The uncyclized product 9 was obtained as a white solid; $\mathrm{mp}$ 49.1-51.7 ${ }^{\circ} \mathrm{C} ;[\alpha]_{\mathrm{D}}+20.3\left(c 0.45, \mathrm{CHCl}_{3}\right)$; IR $v_{\max } / \mathrm{cm}^{-1}$ : $3360(\mathrm{NH}), 1610(\mathrm{C}=\mathrm{O}) ;{ }^{1} \mathrm{H} \mathrm{NMR}\left(200 \mathrm{MHz}, \mathrm{CDCl}_{3}, \delta\right.$, $J \mathrm{~Hz}) 7.68\left(2 \mathrm{H}, \mathrm{d}, J_{2^{\prime}, 3^{\prime}} 7.4,2^{\prime}-\mathrm{H}\right)$; 7.39-7.25 $(18 \mathrm{H}, \mathrm{m}$, Ar); $6.69\left(1 \mathrm{H}, \mathrm{dd}, J_{\mathrm{NH}, 6} 7.1, J_{\mathrm{NH}, 6^{\prime}} 3.7, \mathrm{~N}-H\right) ; 6.53(1 \mathrm{H}, \mathrm{d}$, $\left.J_{9,8} 15.9,9-\mathrm{H}\right) ; 6.29\left(1 \mathrm{H}, \mathrm{ddd}, J_{8,7} 6.8, J_{8,7}, 5.8,8-\mathrm{H}\right) ; 4.87$ $\left(1 \mathrm{H}, \mathrm{d}, J_{\text {gem }} 11.7\right.$, one of $\left.\mathrm{PhCH}_{2}\right) ; 4.86\left(1 \mathrm{H}, \mathrm{d}, J_{\text {gem }} 12.0\right.$, one of $\left.\mathrm{PhCH}_{2}\right)$; 4.76-4.64 (4 H, two of $\left.\mathrm{PhCH}_{2}, 1-\mathrm{H}, 7-\mathrm{H}\right)$; $4.29\left(1 \mathrm{H}, \mathrm{dd}, J_{\text {gem }} 12.5, J_{7,8} 6.8\right.$, one of 7-H); $4.02(1 \mathrm{H}$, dd, $\left.J_{2,3} 9.7, J_{2,1} 3.4,2-\mathrm{H}\right) ; 3.97-3.88(4 \mathrm{H}, \mathrm{m}, 3-\mathrm{H}, 4-\mathrm{H}, 5-$ $\mathrm{H}$, one of 6-H); $3.45(1 \mathrm{H}, \mathrm{m}$, one of $6-\mathrm{H}) ; 3.30(3 \mathrm{H}, \mathrm{s}$, $\mathrm{MeO}) ;{ }^{13} \mathrm{C} \mathrm{NMR}\left(50 \mathrm{MHz}, \mathrm{CDCl}_{3}, \delta\right) 167.7(\mathrm{C}=\mathrm{O}) ; 138.8$, 138.6 (2 ipso $\mathrm{C}$ of benzyl group); 136.6 (ipso $\mathrm{C}$ of cinnamyl group); 134.4 (1'-C); 131.6, 128.7, 128.6, 128.5, 128.2, 128.0, 127.9, 127.8, 126.9 (Ar); 126.1 (8-C); 99.0 (1-C); 79.0, 76.6 (2-C, 3-C, 4-C); 73.8, 73.7 (2 x PhCH 7-C); 68.6 (5-C); 55.5 (MeO); 41.2 (6-C); ESI(+)-MS m/ $z$ found: 594.2607, $\mathrm{m} / \mathrm{z}$ calculated for $\left[\mathrm{C}_{37} \mathrm{H}_{39} \mathrm{NO}_{6}+\mathrm{H}\right]^{+}$: 594.2856; $\mathrm{m} / \mathrm{z}$ found: 616.2512 , calculated for $\left[\mathrm{C}_{37} \mathrm{H}_{39} \mathrm{NO}_{6}\right.$ $+\mathrm{Na}]^{+}:$616.2675; $\mathrm{m} / \mathrm{z}$ found: 632.2560 , calculated for $\left[\mathrm{C}_{37} \mathrm{H}_{39} \mathrm{NO}_{6}+\mathrm{K}\right]^{+}: 632.2415$.

\section{Acknowledgments}

M. A. F. Prado, R. J. Alves and C. G. Queiroga thank the Conselho Nacional de Desenvolvimento Científico e Tecnológico (CNPq) for fellowship. M. T. Oliveira thanks the Coordenação de Aperfeiçoamento de Pessoal de Nível Superior (CAPES) for fellowship. M. N. Eberlin and L. S. Santos thank the Brazilian National Research Council (CNPq) and Fundação de Amparo à Pesquisa do Estado de São Paulo (FAPESP) for financial support.

\section{References}

1. Prado, M. A. F.; Alves, R. J.; Souza Filho, J. D.; Alves, R. B.; Pedrosa, M. T. C.; Prado, R. F.; Faraco, A. A. G.; J. Chem. Soc., Perkin Trans. 1 2000, 1853.

2. Binatti, I.; Prado, M. A. F.; Alves, R. J.; Souza-Filho, J. D.; J. Braz. Chem. Soc. 2002, 13, 570.

3. Faraco, A. A. G.; Prado, M. A. F.; Alves, R. B; Alves, R. B.; Faraco, R. F. P; Alves, R. J.; Souza-Filho, J. D.; Meurer, E. C.; Eberlin, M. N.; Tetrahedron Lett. 2004, 45, 3317.

4. Faraco, A. A. G.; Prado, M. A. F.; Alves, R. J.; Souza-Filho, J. D.; Alves, R. B.; Faraco, R. F.; Synth. Commun. 2003, 33, 463.

5. Dias, D. F.; Prado, M. A. F.; Pinto, G. D.; Alves, R. J. Ales, R. B.; Souza-Filho, J. D.; Quim. Nova 2006, 29, 444.

6. Oliveira, R. B.; Souza-Filho, J. D.; Prado, M. A. F.; Alves, R. J.;. Eberlin, M. N.; Meurer, E. C.; Santos L. S.; Tetrahedron 2004, 60, 9901.

7. Oliveira, R. B.; Alves, R. J.; Souza-Filho, J. D.; Prado, M. A. F; J. Braz. Chem. Soc. 2003, 14, 442.

8. Binatti, I.; Alves, R. B.; Prado, M. A. F.; Alves, R. J.; SouzaFilho, J. D.; Dias, D. F.; Quim. Nova 2005, 28, 1023.

9. Porter, N. A.; Chang, V. H. T.; J. Am. Chem. Soc. 1987, 109, 4976.

10. Gibson, S. E.; Guilo, N.; Tozer, M. J.; Chem. Commun. 1997, 637.

11. Chattopadhayay, P.; Mukherjee, M.; Ghosh, S.; Chem. Commun. 1997, 2139.

12. Ghosh, A. K.; Ghosh, K.; Pal, S.; Ghatak, U. R.; J. Chem. Soc., Chem. Commun. 1993, 809.

13. Ghosh, K.; Ghosh, A. K.; Ghatak, U. R.; J. Chem. Soc., Chem. Commun. 1994, 629.

14. Ghosh, K.; Ghatak, U. R.; Tetrahedron Lett. 1995, 36, 4897.

15. Nandi, A.; Mukhopadhyay, R.; Chattopadhyay. P.; J. Chem. Soc., Perkin Trans. 1 2001, 3346.

16. Nandi, A.; Chattopadhyay, P.; Tetrahedron Lett. 2002, 43, 5977.

17. Hall, D. M.; Carbohydr. Res. 1980, 86, 158.

18. Fréchet, M. J.; Baer, H. H.; Can. J. Chem. 1975, 53, 670.

19. Bell, D. J.; Lorber, J.; J. Chem. Soc. 1940, 453.

20. Garegg, P. J.; Samuelson, B.; J. Chem. Soc. Perkin Soc., Perkin Trans. 1 1980, 2866.

21. Umezawa, S.; Nishimura, Y.; Hata, Y.; Tsuchiya, T.; J. Antibiot. 1974, 27, 722.

22. Pietraszkiewicz, M.; Jurckzak, J.; Tetrahedron 1984, 40, 2967.

23. Dufour, M.; Gramain, J. C.; Husson, H. P.; Sinibaldi, M. E.; Troyn, Y.; Synth. Commun. 1992, 22, 189. 
24. Beak, P.; Musick, T. J.; Chen, C. W.; J. Am. Chem. Soc. 1988, 110, 3538

25. Beckwith, A. L. J.; Drok, K.; Maillard, B.; Degueil-Castaing, M; Philippon, A.; Chem. Commun. 1997, 499.

26. Marinovic, N. N.; Ramanathan, H.; Tetrahedron Lett. 1983, 24, 1871.

27. Walling, C.; Tetrahedron 1985, 41, 3887.

28. Baldwin, J. E.; Adlington, R. M.; Ramcharitar, S. H.; Tetrahedron 1992, 48, 3413.

29. Baul, T. S. B.; Dhar, S.; Pyke, S. M.; Tiekink, E. R. T.; Rivarola, E.; Butcher, R.; Smith, F. E.; J. Organomet. Chem. 2001, 633, 7.

30. Natk, M.; Pokharia, S.; Eng, G.; Song, X.; Kumar, A.; Eur. J. Med. Chem. 2005, 40, 289.

31. Baul, T. S.; Singh, K. S.; Song, X.; Zapata, A.; Eng, G.; Lycka, A.; Linden, A.; J. Organomet. Chem. 2004, 689, 4702.
32. Wolff, S.; Hoffmann, H. M. R.; Synthesis 1988, 760.

33. Hoffmann, H. M. D.; Schmidt, B.; Wolff, S.; Tetrahedron 1989, 95, 6113.

34. Murat, M.; Watanabe, S.; Masuda, Y.; Synlett 2000, 1043.

35. Zippi, E. M.; Plourde, G. W.; Satyamurthy, N.; J. Label. Compd. Radiopharm. 1995, 36, 361.

36. Curran, P. D.; Synthesis 1988, 417.

37. Fossey, J.; Lefort D.; Sorba, J. ; Free Radicals in Organic Chemistry, John Wiley \& Sons: Chichester, 1995.

38. Santos, L. S.; Pavam, C. H.; Almeida, W. P.; Coelho, F.; Eberlin, M. N.; Angew. Chem., Int. Ed. 2004, 43, 4330.

Received: September 8, 2006 Web Release Date: March 16, 2007

FAPESP helped in meeting the publication costs of this article. 